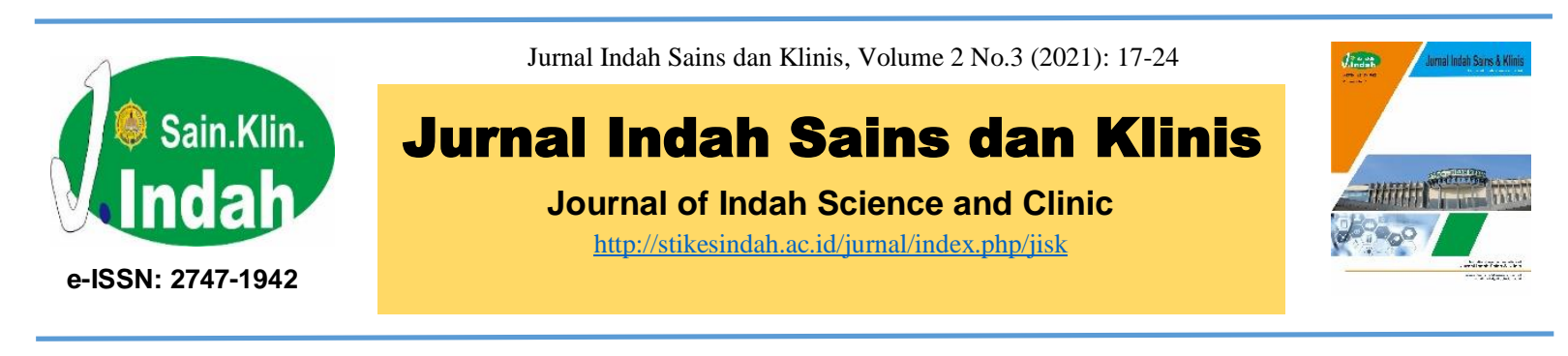

\title{
Pembuatan Sabun Padat Antiseptik Ekstrak Etanol Kulit Jeruk Lemon (Citrus limon (L.) Burm. f.)
}

\author{
Eka Margareth $^{1 *}$, Nova Florentina ${ }^{1}$, Barita Aritonang ${ }^{2}$, Ahmad Hafizullah $^{2}$ \\ ${ }^{1,2}$ Program Studi Teknik Laboratorium Medik, Fakultas Pendidikan Vokasi Universitas Sari Mutiara Indonesia, \\ Medan 20124, Indonesia; . .Program Studi Kimia, Fakultas Sains, Teknologi dan Informasi Universitas Sari \\ Mutiara Indonesia, Medan 20124, Indonesia. *Corresponding author: eka margaret@yahoo.com
}

Received: 24 Oktober 2021; Revised: 29 Nopember 2021; Accepted: 1 Desember 2021

DOI: $10.52622 /$ jisk.v2i3.34

\begin{abstract}
One of the herbal plants with antibacterial properties that it can use in solid antiseptic soap is lemon peel (Citrus limon (L.) Burm.F.). This study aims to determine the optimum composition of antiseptic solid soap preparations from the ethanolic extract of lemon peel based on the requirements set by SNI 06-4085-1996 and the antibacterial activity test. The antibacterial activity test was carried out by the good method. Examination of Simplicia characteristics was carried out by phytochemical screening test. The antiseptic solid soap preparation was performed by organoleptic test, $\mathrm{pH}$ test, homogeneity test, high foam test, and antibacterial activity test. The concentration variations of antiseptic solid soap preparations were $\mathrm{F} 1(5 \%), \mathrm{F} 2(10 \%)$, and $\mathrm{F} 3(15 \%)$. Based on the results of research that has been carried out, the results of phytochemical screening tests for lemon peels (Citrus limon (L.) Burm.F.) contain secondary metabolites, namely alkaloids, flavonoids, and triterpenoids that function as antibacterial. Antiseptic solid soap made from ethanolic extract of lemon peel has met the requirements set by SNI 06-4085-1996, namely a solid and homogeneous soap with a lemon scent with a pH of 8.71-10.52, high foam 4.7-4.9 cm, as well as free alkali in a safe condition against the skin. Based on the results of the antibacterial activity test of solid antiseptic soap, the ethanolic extract of lemon peel (Citrus limon (L.) Burm.F.) can inhibit the growth of Staphylococcus aureus bacteria. At a concentration of F1(5\%) has a zone of moderate inhibition of $10.26 \mathrm{~mm}$; at concentration F2(10\%) has a strong inhibition zone of $11.78 \mathrm{~mm}$; at the concentration of F3(15\%) has a strong inhibition zone of $12.57 \mathrm{~mm}$. Lemon peel extract can be formulated into a solid antiseptic soap with an optimum concentration of F3 (15\%).
\end{abstract}

Keywords: Antiseptic solid soap preparation, Lemon peel extract, Antibacterial activity

\begin{abstract}
Abstrak
Salah satu tanaman herbal yang memiliki sifat antibakteri dapat digunakan dalam bentuk sediaan sabun padat antiseptik adalah kulit buah jeruk lemon (Citrus limon (L.) Burm.F.). Penelitian ini bertujuan untuk menentukan komposisi optimum sediaan sabun padat antiseptik dari ekstrak etanol kulit jeruk lemon berdasarkan persyaratan yang ditetapkan oleh SNI 06-4085-1996 serta uji aktifitas antibakteri. Uji aktivitas antibakteri dilakukan dengan metode sumuran. Pemeriksaan karakteristik simplisia dilakukan dengan uji skrining fitokimia. Evaluasi sediaan sabun padat antiseptik dilakukan dengan uji
\end{abstract}


organoleptik, uji pH, uji homogenitas, uji tinggi busa dan uji aktivitas antibakteri. Variasi konsentrasi sediaan sabun padat antiseptik adalah F1(5\%), F2(10\%) dan F3(15\%). Berdasarkan hasil penelitian yang telah dilakukan hasil uji skrining fitokimia kulit jeruk lemon (Citrus limon (L.) Burm.F.) mengandung senyawa metabolit sekunder yaitu alkaloid, flavonoid dan triterpenoid berfungsi sebagai antibakteri. Sabun padat antiseptik yang dibuat dari ekstrak etanol kulit jeruk lemon sudah memenuhi persyaratan yang ditetapkan oleh SNI 06-4085-1996 yaitu sabun berbentuk padat dan homogen, beraroma jeruk lemon dengan $\mathrm{pH} 8,71-10.52$, tinggi busa 4,7-4,9 $\mathrm{cm}$, serta alkali bebas dalam kondisi aman terhadap kulit. Berdasarkan hasil uji aktivitas antibakteri sediaan sabun padat antiseptik ekstrak etanol kulit jeruk lemon (Citrus limon (L.) Burm.F.) dapat menghambat pertumbuhan bakteri Staphylococcus aureus. Pada konsentrasi F1(5\%) memiliki zona daya hambat sedang sebesar 10.26 $\mathrm{mm}$; pada konsentrasi F2(10\%) memiliki zona daya hambat kuat sebesar $11.78 \mathrm{~mm}$; pada konsentrasi F3(15\%) memiliki zona daya hambat kuat sebesar $12.57 \mathrm{~mm}$. Ekstrak kulit jeruk lemon dapat diformulasikan menjadi sabun padat antiseptik dengan konsentrasi yang optimum yaitu F3(15\%).

Kata Kunci : Sediaan sabun padat antiseptik, Ekstrak kulit jeruk lemon, Aktivitas antibakteri.

\section{PENDAHULUAN}

Kesehatan tubuh harus selalu dijaga supaya tidak mudah terserang penyakit infeksi yang disebabkan oleh mikroorganisme. Penyakit infeksi dapat terjadi ketika mikroorganisme masuk ke dalam tubuh dan menyerang sistem organ tubuh sehingga menyebabkan daya tahan tubuh menjadi lemah $(1,2)$. Mikroorganisme yang dapat menyebabkan terjadinya penyakit infeksi adalah bakteri Staphylococcus aureus. Bakteri Staphylococcus aureus merupakan bakteri gram positif penyebab terjadinya infeksi pada kulit diantaranya bisul, jerawat, pneumonia, meningitis, dan arthritits. Merawat kesehatan kulit sangat perlu dilakukan, agar tidak mudah terserang penyakit infeksi, yang disebabkan oleh bakteri Staphylococcus aureus (3).

Bentuk sediaan farmasi yang dapat digunakan untuk menjaga kesehatan kulit agar tidak mudah terserang penyakit infeksi adalah sabun. Sabun merupakan salah satu produk industri kosmetik yang dihasilkan dari reaksi antara minyak atau lemak dengan basa $\mathrm{KOH}$ atau $\mathrm{NaOH}$ melalui proses saponifikasi. Proses saponifikasi merupakan reaksi pemutusan gliserol rantai trigliderisida melalui reaksi dengan natrium hiroksida $(\mathrm{NaOH})$. Sabun selama ini banyak digunakan oleh masyarakat untuk membersihkan tubuh dari debu dan kotoran serta untuk mengobati penyakit kulit yang disebabkan oleh bakteri Staphylococcus aureus. Sabun padat antiseptik merupakan sabun, yang dapat menghambat dan membunuh pertumbuhan bakteri Staphylococcus aureus pada jaringan permukaan kulit. Antiseptik merupakan senyawa kimia yang digunakan untuk membunuh atau menghambat pertumbuhan Staphylococcus aureus pada permukaan kulit dan membran mukosa, yang bertujuan untuk mencegah terjadinya infeksi agar tidak menjadi parah $(4,5)$.

Salah satu tanaman herbal yang dapat digunakan dalam bentuk sediaan sabun padat antiseptik yang memiliki sifat antibakteri adalah kulit buah jeruk lemon. Kulit buah jeruk lemon (Citrus limon (L.) Burm.F.) mengandung senyawa bioaktif seperti alkaloid, flavonoid, terpenoid dan asam sitrat yang berfungsi sebagai antibakteri, yang mampu menghambat dan membunuh pertumbuhan bakteri Staphylococcus aureus $(6,7)$.

Berdasarkan penelitian sebelumnya mengenai pembuatan sabun padat antispetik dari tanaman herbal sebagai antibakteri telah dilakukan oleh (8) melaporkan bahwa sediaan sabun padat ekstrak etanol bawang putih memiliki aktifitas antibakteri yang dapat menghambat pertumbuhan bakteri Staphylococcus epidermis. Berdasarkan hasil penelitian yang telah dilakukan formulasi optimum sediaan sabun padat antiseptik diperoleh pada konsentrasi $25 \%$ memiliki diameter zona hambat sebesar 15,3 mm. (9) melaporkan bahwa sediaan sabun padat antibakteri ekstrak etanol daun serai wangi (Citronella oil) efektif menghambat pertumbuhan bakteri Staphylococcus aureus, dimana zona hambat optimum pada formulasi F3 sebesar $8,58 \mathrm{~mm}$. Semakin banyak ekstrak daun serai wangi yang ditambahkan maka semakin besar zona hambatnya. (10) melaporkan bahwa sediaan sabun mandi padat ekstrak etanol daun Gedi dapat menghambat bakteri Staphylococcus epidermidis yang memiliki daya hambat terkuat pada konsentrasi 3\% dengan diameter zona hambat 14,8 mm.

Penelitian ini bertujuan untuk menentukan komposisi optimum pembuatan sabun padat antiseptik ekstrak etanol kulit jeruk lemon terhadap daya hambat bakteri Staphylococcus aureus. Pelarut yang digunakan untuk mengekstrak kulit jeruk lemon adalah etanol. Alasan memilih etanol sebagai perlarut 
karena tidak beracun, kapang dan bakteri sulit tumbuh serta dapat melarutkan alkaloid, glikosida, flavonoid, steroid, tanin dan saponin. Uji aktivitas antibakteri sabun padat antiseptik ekstrak kulit buah jeruk lemon (Citrus limon (L.) Burm.F.) dilakukan dengan metode difusi sumuran. Alasan memilih metode difusi sumuran karena lebih mudah mengukur luas zona hambat yang terbentuk dan bakteri yang beraktivitas tidak hanya dipermukaan atas nutrien agar tetapi juga sampai ke bawah. Sabun padat antiseptik diharapkan dapat menjadi salah satu alternatif pengobatan infeksi penyakit kulit yang disebabkan oleh bakteri Staphylococcus aureus.

\section{METODE PENELITIAN}

\section{Bahan dan alat}

Bahan yang digunakan adalah bakteri Staphylococcus aureus, kulit buah jeruk lemon, etanol $96 \%$, kloroform, serbuk magnesium, amil alkohol, $n$-heksan, $\mathrm{NaOH}$, natrium klorida jenuh, pereaksi Mayer, amil alkohol, pereaksi Dragendorff, pereaksi Bouchardat, pereaksi Liebermann-Burchad, pereaksi Besi (III) klorida 1\%, pereaksi asam klorida 2N, pereaksi Timbal (II) asetat 0,4M, aquadest, Nutrient Agar, MHA, asam stearat, gliserin, sukrosa, indikator fenolftalein, $\mathrm{KOH}$, minyak kelapa, minyak kelapa sawit, minyak zaitun, neraca analitik, satu set alat destilasi uap, termometer, klem dan statif, cawan petri, laminar air flow, inkubator, cotton bud, mikroskop, autoklaf, mistar, ose, aluminium foil, bunsen, kaki tiga, cetakan sabun, oven, desikator, ball filler, hotplate, panci, buret, kertas saring, penangas air, dan serbet.

\section{Pembuatan Serbuk Simplisia (Citrus limon (L.) Burm.F.)}

Sampel kulit jeruk lemon (Citrus limon (L.) Burm.F.) yang telah dikumpulkan dilakukan sortasi basah, kemudian dicuci dengan air bersih mengalir. Setelah itu, kulit jeruk lemon dipotong kecil-kecil dan dilakukan pengeringan dibawah sinar matahari. Setelah dilakukan pengeringan, sampel kulit jeruk lemon dilakukan sortasi kering, kemudian sampel dijadikan serbuk dengan cara diblender dan diayak. Sampel kulit jeruk lemon yang sudah menjadi serbuk simplisia disimpan dalam wadah tertutup. Sampel kulit buah jeruk lemon ditimbang sebanyak $500 \mathrm{~g}$, dicuci bersih setelah itu ditiriskan airnya dengan cara diangin-anginkan, selanjutnya dikeringkan ke dalam oven pada suhu $100{ }^{\circ} \mathrm{C}$ selama $24 \mathrm{jam}$. Sampel kulit buah jeruk lemon yang sudah kering dihaluskan dengan blender sehingga menjadi simplisia dan diayak hingga lolos 100 mesh. Serbuk simplisia selanjutnya, diekstraksi dengan cara maserasi.

\section{Pembuatan Ekstrak Kulit Jeruk Lemon (Citrus limon (L.) Burm.F.)}

Pembuatan ekstrak kulit jeruk lemon (Citrus limon (L.) Burm.F.) dilakukan dengan metode maserasi. Timbang kulit jeruk lemon sebanyak $1 \mathrm{~kg}$, bersihkan kulit jeruk lemon dari kotoran, kemudian cuci dengan air mengalir hingga bersih, kemudian tiriskan. Kulit jeruk lemon dikeringan dengan menggunakan sinar matahari. Kulit jeruk lemon yang telah kering, kemudian dihaluskan menjadi serbuk menggunakan blender. Timbang simplisia kulit jeruk lemon sebanyak 100 gram. Masukkan simplisia kulit jeruk lemon kedalam tabung gelap ukuran 2 liter rendam dengan etanol 96\% sebanyak 1 liter. Aduk dan diamkan selama 3 × 24 jam dalam suhu kamar. Kemudian, setelah 3 x 24 jam rendaman simplisia kulit jeruk lemon disaring dengan menggunakan corong dan kertas saring sampai ampasnya terpisah. Hasil maserasi dimasukkan ke dalam labu untuk diuapkan menggunakan rotary evaporator untuk menghasilkan ekstrak kental (11).

\section{Skrining Fitokimia}

Pemeriksaan Alkaloida Sampel uji ditimbang sebanyak 0,5 g kemudian ditambahkan $1 \mathrm{ml}$ asam klorida $2 \mathrm{~N}$ dan $9 \mathrm{ml}$ air suling, dipanaskan diatas penangas air selama 2 menit, didinginkan dan disaring. Filtrat yang diperoleh dipakai untuk uji alkaloida, diambil 3 tabung reaksi, lalu kedalamnya dimasukkan $0,5 \mathrm{ml}$ filtrat. Masing-masing tabung reaksi ditambahkan pereaksi yang berbeda. Tabung reaksi 1: ditambahkan 2 tetes pereaksi Mayer. Tabung reaksi 2: ditambahkan 2 tetes pereaksi Bouchardat. Tabung reaksi 3: ditambahkan 2 tetes pereaksi Dragendorff. Alkaloid positif jika terjadi endapan atau kekeruhan pada paling sedikit dua dari tiga percobaan diatas (12).

\section{Pemeriksaan Flavonoida}

Sebanyak $10 \mathrm{~g}$ sampel uji ditambahkan $10 \mathrm{ml}$ air panas, dididihkan selama 5 menit dan disaring dalam keadaan panas, kedalam $5 \mathrm{ml}$ filtrat ditambahkan $0,1 \mathrm{~g}$ serbuk magnesium dan $1 \mathrm{ml}$ asam klorida 
pekat dan $2 \mathrm{ml}$ amil alkohol, dikocok dan dibiarkan memisah. Flavonoida positif jika terjadi warna merah atau kuning atau jingga pada lapisan amil alkohol (12).

\section{Pemeriksaan Saponin}

Sampel uji ditimbang sebanyak $0,5 \mathrm{~g}$ dan dimasukkan kedalam tabung reaksi, lalu ditambahkan $10 \mathrm{ml}$ air panas, dinginkan kemudian dikocok kuat-kuat selama 10 detik. Jika terbentuk busa setinggi $1-10 \mathrm{~cm}$ yang stabil dan tidak kurang dari 10 menit dan tidak hilang dengan penambahan 1 tetes asam klorida $2 \mathrm{~N}$ menunjukkan adanya saponin (12).

\section{Pemeriksaan Tanin}

Sampel uji ditimbang sebanyak1g, didihkan selama 3 menit dalam $100 \mathrm{ml}$ air suling lalu didinginkan dan disaring . Larutandiambil $2 \mathrm{ml}$ ditambahkan 1-2 tetes pereaksi besi(III)klorida $1 \%$. Jikaterjadi warna biru kehitaman atau hijau kehitaman menunjukkan adanya tanin.

\section{Pemeriksaan Steroid/Triterpenoid}

Sebanyak $1 \mathrm{~g}$ sampel uji dimaserasi selama 2 jam dengan $20 \mathrm{ml} \mathrm{n}$-heksan, lalu disaring. Filtrat diuapkan dalam cawan penguap. Pada sisa ditambahkan beberapa tetes pereaksi Liebermann-Burchad. Timbulnya warna biru atau biru hijau menunjukkan adanya steroid, sedangkan warna merah, merah muda atau ungu menunjukkan adanya triterpenoid.

\section{Pembuatan sabun padat antiseptik}

Pembuatan Sabun Minyak kelapa dan minyak kelapa sawit dicampurkan dalam gelas beker hingga homogen. Setelah itu $\mathrm{NaOH}$ dilarutkan dalam akuades, kemudian dicampurkan dengan minyak kelapa dan minyak kelapa sawit serta minyak zaitun yang dituangkan secara perlahan-lahan sambil diaduk hingga homogen. Kemudian ditambahkan ekstrak kulit jeruk lemon dengan variasi konsentrasi masing-masing sebanyak $0 ; 2,0 ; 2,5$; dan 3,0 g. Formulasi pembuatan sabun padat antiseptik disajikan pada Tabel 1.

Tabel 1. Rancangan Formulasi Sediaan Sabun Padat Antiseptik

\begin{tabular}{lcccc}
\multicolumn{1}{c}{ Bahan (g) } & F0 & F1 & F2 & F3 \\
\hline Ekstrak Kulit jeruk lemon & 0 & 5 & 10 & 15 \\
Minyak kelapa & 20 & 20 & 20 & 20 \\
Minyak kelapa sawit & 30 & 30 & 30 & 30 \\
Minyak Zaitun & 10 & 10 & 10 & 10 \\
NaOH & 10 & 10 & 10 & 10 \\
Pewangi & 5 & 5 & 5 & 5 \\
Aquades & \multicolumn{5}{c}{ secukupnya } \\
\hline
\end{tabular}

Keterangan :

$\mathrm{F} 1=$ Formula 1 sediaan sabun padat ekstrak kulit jeruk lemon konsentrasi $5 \%$.

F2 = Formula 2 sediaan sabun padat ekstrak kulit jeruk lemon konsentrasi 10\%

F3 = Formula 3 sediaan sabun padat ekstrak kulit jeruk lemon konsentrasi 15\%.

\section{Uji Aktivitas Antibakteri}

Pengujian aktivitas antibakteri pada penelitian ini digunakan metode sumuran. Media MHA yang telah disterilkan sebanyak $25 \mathrm{ml}$ dituangkan kedalam 3 cawan petri steril dan dibiarkan memadat. Selanjutnya pada media tersebut dibuat lubang sumuran dengan diameter $7 \mathrm{~mm}$. Suspensi bakteri uji dicampurkan dengan media MHA kemudian dimasukkan dalam tiap cawan petri dan diinokulasikan secara merata. Sumuran yang telah dibuat dimasukkan konsentrasi sediaan sabun padat antiseptik ekstrak etanol kulit jeruk lemon yang telah disuspensikan dengan cara $5 \mathrm{~g}$ sabun dilarutkan dalam 10 $\mathrm{ml}$ air kemudian diambil 50 $\mu$ l ekstrak dari masing-masing konsentrasi 5\%, 10\%, 15\%, serta kontrol positif dan kontrol negatif yang telah dilarutkan dengan aquadest. Inokulum ini selanjutnya diinkubasi selama 24 jam pada suhu $35-37{ }^{\circ} \mathrm{C}$. Kepekaan bakteri uji diamati dengan mengukur zona hambat di sekeliling media yang telah dilubangi secara seksama yang ditandai dengan adanya daerah bening pada sekitar sumuran. Zona hambat yang terbentuk kemudian diukur dalam satuan millimeter (mm) menggunakan jangka sorong juga termasuk diameter lubang sumuran. 


\section{HASIL DAN PEMBAHASAN}

\section{Hasil Identifikasi Tanaman}

Hasil identifikasi tanaman yang dilakukan di Herbarium Medanense (MEDA) Universitas Sumatera Utara menyatakan bahwa tanaman yang digunakan dalam penelitian ini ialah termasuk suku Rutaceae, jenis (Citrus limon (L.) Burm.f.).

\section{Hasil Skrining Fitokimia}

Skrining fitokimia dilakukan agar mengetahui kandungan senyawa aktif atau senyawa metabolit sekunder yang terdapat dalam ekstrak kulit buah jeruk lemon (Citrus limon (L.) Burm.F.). Skrining fitokimia pada ekstrak kulit buah jeruk lemon (Citrus limon (L.) Burm.F.) menunjukkan hasil positif pada uji Alkaloid, flavonoid dan Steroid/Triterpenoid. Hasil skrining fitokimia terhadap serbuk simplisia kulit buah jeruk lemon, dapat dilihat pada Tabel 2.

Tabel 2. Hasil Skrining Fitokimia Kulit Buah Jeruk Lemon

\begin{tabular}{ccccc}
\hline Sampel & Zat Aktif & Pereaksi & Hasil Uji & Keterangan \\
\hline Serbuk simplisia & Alkaloid & Bouchardat & Endapan warna jingga & Positif \\
kulit jeruk & Flavonoid & Amil alkohol & Warna Kuning & Positif \\
lemon & Triterpenoid & N-heksan & Warna merah muda & Positif \\
\hline
\end{tabular}

Hasil skrining fitokimia menunjukkan bahwa serbuk simplisia kulit buah jeruk lemon mengandung senyawa alkaloid, flavonoid, steroid/triterpenoid, yang berperan sebagai antibakteri. Hasil uji alkaloid serbuk simplisia kulit buah jeruk lemon dengan pereaksi Bouchardat menghasilkan endapan warna jingga, dengan pereaksi Dragendorff menghasilkan endapan warna kuning jingga dengan pereaksi Mayer menghasilkan endapan putih. Alkaloid berperan mengganggu komponen penyusun peptidoglikan pada sel bakteri sehingga lapisan dinding sel tidak terbentuk secara utuh sehingga menyebabkan kematian sel tersebut.

Hasil uji flavonoid serbuk simplisia kulit buah jeruk lemon dengan pereaksi amil alkohol menghasilkan warna kuning. Flavonoid memiliki kemampuan untuk menghambat pertumbuhan bakteri dengan cara menyebabkan kerusakan pada membran sel dan menghambat sintesis makromolekul sel bakteri. Hasil uji steroid/triterpen serbuk simplisia kulit buah jeruk lemon menghasilkan warna merah muda, membuktikan kulit buah jeruk lemon mengandung senyawa terpen. Triterpenoid memiliki kemampuan untuk menghambat pertumbuhan bakteri dengan cara bereaksi dengan purin dan membran luar sel bakteri membentuk ikatan polimer yang kuat sehingga mengakibatkanrusaknya purin. Rusaknya purin yang merupakan pintu keluar masuknya senyawa akan mengurangi permeabilitas membran sel bakteri yang akan mengakibatkan sel bakteri kekurangan nutrisi dan akan menghambat pertumbuhan bakteri atau mengalami kematian $(6,7)$

\section{Evaluasi Sediaan Sabun Padat Hasil Uji Organoleptik}

Uji organoleptik adalah pengujian terhadap fisik sabun meliputi warna, bau dan bentuk. Hasil pengamatan organoleptik dapat dilihat pada Tabel 3.

Tabel 3. Hasil Uji Organoleptik

\begin{tabular}{cccc}
\hline Sediaan & Bentuk & Aroma & Warna \\
\hline F1 & Padat dan halus & Wangi jeruk lemon & Hijau muda \\
F2 & Padat dan halus & Wangi jeruk lemon & Hijau muda \\
F3 & Padat dan halus & Wangi jeruk lemon & Hijau muda \\
\hline
\end{tabular}

Hasil pengamatan organoleptik bentuk sabun antiseptik ekstrak kulit jeruk lemon untuk semua formulasi berbentuk padat, hal ini dikarenakan penggunaan minyak kelapa dan minyak sawit serta minyak zaitun berfungsi untuk mengeraskan sabun. Bentuk sabun antiseptik yang padat membutikan bahwa sabun ini sudah memenuhi syarat dari SNI 06-3532-1994. Warna yang dihasilkan pada semua formula sabun padat antiseptik yaitu warna hijau yang dipengaruhi oleh penambahan ekstrak kulit jeruk 
lemon. Warna tersebut disebabkan karena adanya klorofil pada kulit jeruk lemon. Berdasarkan hasil yang diperoleh, menunjukan bahwa semua formulasi pada penelitian ini sudah memenuhi standar yang telah ditetapkan SNI.

\section{Hasil Uji pH Sediaan Sabun Padat Antiseptik}

Derajat Keasaman $(\mathrm{pH})$ merupakan salah satu parameter kualitas sabun. Sabun yang memiliki $\mathrm{pH}$ terlalu tinggi dapat meningkatkan daya absorpsi kulit, sehingga kulit menjadi gatal atau mengelupas dan dapat menyebabkan kulit kering. Hasil uji pH dapat dilihat dalam Tabel 4.

Tabel 4. Hasil Uji pH

\begin{tabular}{ccc}
\hline Sediaan & pH & Keterangan \\
\hline F1 & 8.71 & Memenuhi syarat \\
F2 & 9.09 & Memenuhi syarat \\
F3 & 10.52 & Memenuhi syarat \\
\hline
\end{tabular}

Hasil pengujian $\mathrm{pH}$ dari ketiga formulasi sediaan sabun padat antiseptik adalah 8.71-10.52, bersifat basa. Hal ini menunjukkan bahwa semakin banyak konsentrasi ekstrak etanol kulit jeruk lemon yang ditambahkan kedalam sediaan sabun padat antiseptik maka pH semakin basa. Hal ini dikarenakan bahan dasar penyusun sabun padat tersebut yaitu $\mathrm{NaOH}$ dimana dalam proses pembuatan sabun, $\mathrm{pH}$ dipengaruhi oleh keberadaan larutan alkali $(\mathrm{NaOH})$. Nilai $\mathrm{pH}$ sabun padat ekstrak etanol kulit jeruk lemon yang diperoleh masih memenuhi standart yang telah ditetapkan oleh SNI 06-35321994 dan aman bagi kulit.

\section{Hasil Uji Homogenitas}

Uji homogenitas bertujuan untuk melihat ada tidaknya butiran yang terdapat pada sabun. Cara menguji homogenitas sabun adalah dengan melihat warna dalam basis yang bercampur secara visual. Berdasarkan Tabel 4, data evaluasi yang didapat pada pengamatan homogenitas sediaan sabun padat antiseptik ekstrak kulit jeruk lemon untuk semua formulasi dari minggu ke-1-4 menunjukkan bahwa sabun padat yang dibuat tetap homogen, hal ini ditunjukkan karena tidak adanya partikel pada permukaan sabun padat. Hasil uji homogenitas sabun padat antiseptik ekstrak etanol kulit jeruk lemon dapat dilihat pada Tabel 5.

Tabel 5. Hasil Uji Homogenitas

\begin{tabular}{cc} 
Sediaan & Hasil \\
\hline F1 & Homogen \\
F2 & Homogen \\
F3 & Homogen \\
\hline
\end{tabular}

Hasil uji menunjukkan bahwa ketiga formulasi telah memenuhi syarat SNI 06 3532-1994 yang dapat dilihat dari penyebaran warna yang merata dan tidak ada bagian yang menggumpal atau tidak tercampur. Hal ini karena proses pencampurannya yang maksimal dimana saat pencampuran bahanbahan sabun menggunakan mixer sehingga sabun yang dihasilkan homogen.

\section{Uji Stabilitas Busa}

Stabilitas busa digunakan untuk mengetahui seberapa banyak busa yang dihasilkan oleh sabun padat antiseptik ekstrak etanol kulit jeruk lemon. Salah satu fungsi busa dalam sabun adalah mencegah agar partikel kotoran yang sudah terlarut di air oleh sabun tidak mengendap lagi, sehingga kotoran dapat dibuang bersama air sabunnya. Berdasarkan standar SNI 06-3532, syarat tinggi busa sabun padat yaitu 1,3-22 cm. Hasil dari pengujian stabilitas busa sabun padat antiseptik ekstrak etanol kulit jeruk lemon dapat dilihat pada Tabel 6 . 
Tabel 6. Hasil Uji Tinggi Busa

\begin{tabular}{ccc}
\hline Sediaan & Tinggi busa $(\mathbf{c m})$ & Keterangan \\
\hline F1 & 4,8 & Memenuhi syarat \\
F2 & 4,7 & Memenuhi syarat \\
F3 & 4,9 & Memenuhi syarat \\
\hline
\end{tabular}

Hasil dari ketiga formula diperoleh rata-rata tinggi busa F1 sebesar 4,8 cm; F2 sebesar 4,7 cm; $\mathrm{F} 3$ sebesar $4,8 \mathrm{~cm}$. Tinggi busa terendah ditunjukkan pada F2, sedangkan tinggi busa tertinggi pada F3, berdasarkan standar SNI 06-3532 tinggi busa masih memenuhi persyaratan.

\section{Uji Alkali Bebas}

Uji alkali bebas dilakukan untuk mengetahui jumlah alkali yang tidak terikat oleh asam lemak. Batas ambang kadar alkali dalam sabun yang ditetapkan oleh standar SNI 06-3532-1994 yaitu tidak boleh melebihi $0,1 \%$. Hal ini dikarenakan alkali bersifat keras dan dapat menyebabkan iritasi pada kulit. Hasil uji kadar alkali bebas dapat dilihat pada Tabel 7.

Tabel 7. Hasil Uji Alkali Bebas

\begin{tabular}{ccc}
\hline Sediaan & Kadar alkali bebas & Keterangan \\
\hline F1 & $0,035 \%$ & Memenuhi syarat \\
F2 & $0,046 \%$ & Memenuhi syarat \\
F3 & $0,055 \%$ & Memenuhi syarat \\
\hline
\end{tabular}

Hasil uji alkali bebas sabun padat antiseptik diperoleh kadar masing-masing konsentrasi yaitu $\mathrm{F} 1$ 0,035\%, F2 0,046\%, dan F3 0,055\%. Kadar alkali bebas sabun padat antiseptik ekstrak jeruk kulit lemon memenuhi syarat dan sesuai dengan standar yang ditetapkan oleh SNI 06-3532-1994 yaitu maksimum $\leq 0,1 \%$. Kadar alkali bebas sabun padat antiseptik ekstrak jeruk kulit lemon masih dalam keadaan aman terhadap kulit, hal ini disebabkan reaksi saponifikasi telah optimal dimana semua basa bereaksi sempurna dan habis bereaksi dengan asam lemak pada saat pembentukan sabun.

\section{Uji Aktivitas Antibakteri}

Aktivitas antibakteri ditandai dengan adanya zona bening disekitar sumuran yang berisi sampel uji. Pengujian antibakteri dilakukan dengan metode sumuran dengan cara mengukur diameter zona bening (diameter zona hambat) disekitar sumuran yang berisi sampel uji. Zona hambat $\leq 5 \mathrm{~mm}$ dikategorikan lemah, zona hambat $\geq 6-10 \mathrm{~mm}$ dikategorikan sedang, zona hambat $\geq 11-20 \mathrm{~mm}$ dikategorikan kuat. Hasil pengukuran diameter zona hambat ekstrak kulit jeruk buah lemon ditunjukkan pada Tabel 8.

Tabel 8. Hasil Uji Zona Daya Hambat

\begin{tabular}{ccc}
\hline Sediaan & Zona hambat $(\mathbf{m m})$ & Aktivitas antibakteri \\
\hline F0 & 14,45 & Kuat \\
F1 & 10.26 & Sedang \\
F2 & 11.78 & Kuat \\
F3 & 12.57 & Kuat \\
\hline
\end{tabular}

Berdasarkan Tabel 8 menunjukan bahwa setiap formulasi terjadi peningkatan diameter zona hambat. Pada formulasi F1(5\%) memiliki zona hambat terhadap bakteri sebesar $10.26 \mathrm{~mm}$, F2(10\%) sebesar $11.78 \mathrm{~mm}$, dan F3(15\%) sebesar $12.57 \mathrm{~mm}$. Berdasarkan data tersebut dapat diketahui bahwa perlakuan penambahan ekstrak kulit buah jeruk lemon pada formulasi pembuatan sabun padat antiseptik dapat mempengaruhi kemampuan aktivitas antibakteri Staphylococcus aureus. Hal ini dibuktikan dengan adanya kenaikan nilai diameter daya hambat pada sabun padat antiseptik. Penambahan ekstrak kulit buah jeruk lemon juga mempengaruhi kecepatan difusi zat aktif, semakin banyak ekstrak kulit buah jeruk lemon yang ditambahkan maka semakin cepat difusi yang berpengaruh terhadap besarnya daya hambat antibakteri dan semakin luas diameter zona hambat yang terbentuk. Peningkatan diameter zona hambat karena adanya kandungan zat aktif seperti alkaloid, flavonoid, terpenoid yang terkandung 
dalam kulit jeruk lemon memiliki efek antibakteri yang dapat menghambat mekanisme pertumbuhan bakteri (5).

Sabun padat antiseptik ekstrak etanol kulit jeruk lemon secara signifikan dapat menghambat pertumbuhan bakteri $(\mathrm{p}<0,05)$ yang ditunjukkan adanya zona bening disekitar paper disk (Gambar 1). Zona bening terbentuk karena ekstrak yang ada pada paper disk berdifusi ke agar dan mencegah pertumbuhan bakteri Staphylococcus aureus yang ada di daerah itu. Diduga campuran senyawa flavonoid, alkaloid, terpenoid, sebagai antibakteri yang dapat menghambat pertumbuhan bakteri.

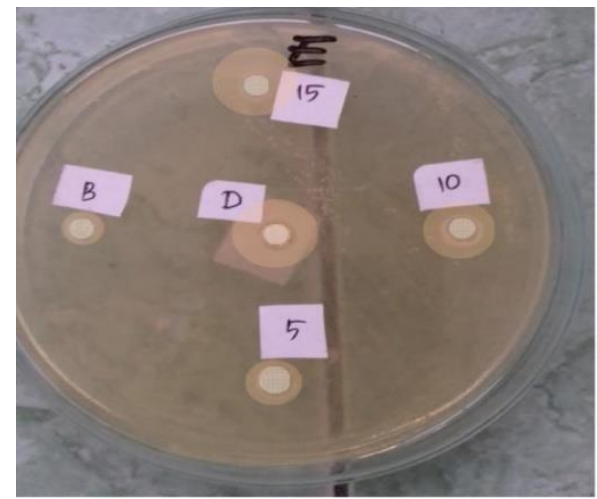

Gambar 1. Diameter Zona Hambat

\section{KESIMPULAN}

Hasil penelitian dapat disimpulkan bahwa ekstrak etanol kulit jeruk lemon (Citrus limon (L.) Burm.f.) dapat diformulasikan menjadi sediaan sabun padat antiseptik dan memenuhi standar SNI 06-4085-1996. Sabun padat antiseptik ekstrak etanol kulit jeruk lemon dengan konsentrasi 5\%, 10\%, dan 15\% menunjukan adanya aktifitas antibakteri pada bakteri Staphylococcus aureus memberikan hasil paling tinggi pada konsentrasi $15 \%$ dengan nilai daya hambat $12.57 \mathrm{~mm}$ kategori kuat.

\section{DAFTAR PUSTAKA}

1. Garna H. Patofisiologi Infeksi Bakteri pada Kulit. Sari Pediatr. 2016;2(4):205-9.

2. Arfani N. Identifikasi Bakteri Staphylococcus Aureus Pada Kulit. Penerbit Kbm Indonesia; 2021.

3. Millah H. Pengaruh pemberian perasaan jeruk nipis (Citrus Aurantifolia S) terhadap daya hambat pertumbuhan staphylococcus aureus dengan menggunakan Metode Difusi”. Wijaya Kusuma Surabaya University; 2020.

4. Aznury M, Serlina A. Optimasi formula pembuatan sabun padat antiseptik alami dengan penambahan ekstrak daun sirih hijau (piper betle 1). Kinetika. 2021;12(1):51-9.

5. Putri AR, Sulistyowati E, Harismah K. Uji antibakteri daun stevia dalam formulasi sabun padat jeruk nipis. EDUSAINTEK. 2019;3.

6. Harahap IS, Halimatussakdiah H, Amna U. Skrining Fitokimia Ekstrak Daun Jeruk Lemon (Citrus limon L.) dari Kota Langsa, Aceh. Quim J Kim Sains dan Terap. 2021;3(1):19-23.

7. Mayasari U, Laoli MT. Karakterisasi simplisia dan skrining fitokimia daun jeruk lemon (citrus limon (1.) burm. f.). KLOROFIL J Ilmu Biol dan Terap. 2018;2(1):7-13.

8. Bernaldez JL, Vicencio MCG. Antibacterial Activity of Soap Formulated from Garlic (Allium sativum L.) Extract. J Adv Microbiol. 2021;63-7.

9. Pratama YE, Melia S, Purwati E. Characteristic and quality microbiology solid soap citronella oil with the addition of Lactobacillus brevis. In: IOP Conference Series: Earth and Environmental Science. IOP Publishing; 2021. p. 12075.

10. Mopangga E, Yamlean PVY, Abdullah SS. Formulasi Sediaan Sabun Mandi Padat Ekstrak Etanol Daun Gedi (Abelmoschus manihot L.) Terhadap Bakteri Staphylococcus epidermidis. PHARMACON. 2021;10(3):1017-24.

11. Lesmono V. BPOM RI.(2011). Acuan sediaan herbal. Jakarta: Badan Pengawasan Obat dan Makanan Republik Indonesia.

12. Depkes RI. Sediaan galenik. Dep Kesehat RI, Jakarta. 1986; 